\title{
ENKELE ASPEKTE VAN EN STREKKINGE IN DIE ONDERWYSERSOPLEIDING
}

(Inougurele rede gehou by die aanvaarding van 'n Ere-professoraat in die Opvoedkunde aan die P.U. vir C.H.O. op 27 Mei 1958, deur prof. J. W. Daneel).

Hooggeagte Here Lede van die Raad van die P.U. vir C.H.O., Hooggeleerde Rektor, Here Professore, Dames en Here Lektore van hierdie Universiteit en van die Onderwyskollege, Geagte Dames- en Herestudente,

Dames en Here,

Die onderwerp van hierdie rede by geleentheid van die aanvaarding van ' $n$ ereprofessoraat is

\section{ENKELE ASPEKTE VAN EN STREKKINGE IN DIE ONDERWYSERSOPLEIDING.}

"The old order changeth, yielding place to new, And God fulfils Himself in many ways,

Lest one good custom should corrupt the world."

\section{A. Lord Tennyson.}

Die geskiedenis van elke gemeenskap word gekenmerk deur periodieke verskuiwings van waardebepalings, veroorsaak deur bepaalde faktore soos politieke en sosiale omwentelinge, wetenskaplike ontdekkings, hervormings op een of ander geestesgebied, die geskrifte en invloed van oorheersende persoonlikhede, diepsinnige denkers en begaafde skeppers van skoonheidsvorme, en deur minder begrensde faktore, die imponderabilia van 'n tydgees wat enersyds dominante persoonlikhede opwerp en andersyds vatbaarheid vir of die behoefte aan 'n nuwe orde bewerkstellig. Die doel van opvoeding, die karakter van die opvoedkundige instellings, en die aard en omvang van die leerplanne daarvan, hang in enige gegewe tydperk ten nouste saam met die heersende maatskaplike en godsdienstige waardebepalings.

Die rigtingloosheid en die onsekerheid ten opsigte van blywende waardebepalings wat die twintigste eeu ten laste gelê word, kan in groot mate toegeskryf word aan ingrypende omwentelinge waaraan die mensdom gedurende die afgelope 150 jaar blootgestel is, soos o.a. die industrialisasie van die meeste lande en die gelykmakingsproses en 
demoralisasie wat twee wêreldoorloë teweeggebring het. Tereg skryf Keyter, met verwysing na die huidige wêreldtoestand van sake: „Sulke periodes van doellose rondtas en soek met betrekking tot die kardinale eise van die lewe laat ook spoedig hulle invloed op die opvoeding en onderwys geld." (')

Die Boyd, Munro of Coetzee van die volgende eeu sal in alle waarskynlikheid die hele twintigste eeu as 'n eeu van "doellose rondtas" kan bestempel, in weerwil van die ongeëwenaarde wetenskaplike vindingrykheid en tegniese vaardigheid daarvan. Die mens is, wat betref die "kardinale eise in die lewe" in die twintigste eeu vergelykbaar met Tennyson se

"An infant crying in the night,

An infant crying for the light:

And with no language but a cry."

Of sy "The feeble soul, a haunt of fears."

Die geskiedskrywer van die toekoms sal egter ook kan verwys na die geweldige vooruitgang van die opvoeding en onderwys gedurende die twintigste eeu: die aanvaarding in alle beskaafde lande van die eis van verpligte onderwys tot by 'n sekere minimumpeil, die wetenskaplike benadering van en bevindings met betrekking tot 'n legio opvoedkundige probleme, die grootskaalse voorsiening van staatsbeheerde en -beplande opvoedkundige fasiliteite, die toepassing van die beginsel van kindgerigte onderwys, ens. Hy sal ook die twintigste eeu kan bestempel as die eeu waarin onderwysersopleiding in menige opsig tot sy reg gekom het.

Nieteenstaande die styging en daling waaraan die opvoeding en onderwys deur die eeue blootgestel is, het een faktor relatief konstant gebly, die eis wat deurgaans die opvoeding en opvoeder opgelê is, $\mathrm{nl}$. die van deugdelikheid ' $n$ eis wat beklemtoon is deur die Prediker (,Vrees God en hou Sy gebooie”); deur Aristoteles ('n goeie karakter); Seneca (Opvoeding moet sedelik wees); Vittorino da Feltre (Hy het gemeen dat naas godsdienstige vorming ,karakteropvoeding waardevoller as verstandsontwikkeling" beskou moet word); $\left(^{\prime}\right)$. Pestalozzi (vorming tot deugdelikheid); Herbart (Die strewe van opvoeding kan saamgevat word in die begrip deugdelikheid); H. Spencer (,the right

(1) Opvoeding en Onderwys. J. de W, Keyter. 1036.

(2) Opvoedkundige Teorie en Praktyk deur die Eeue. J. C. Coetzee. Voortrekker Pers. 1943. 
ruling of conduct in all directions under all circumstances"); ( $\left.{ }^{3}\right)$ W. James (,the organizing . . . . of powers of conduct"). (')

Die geskiedenis van die opvoeding en onderwys in die algemeën en van die onderwysersopleiding in die besonder toon telkemale 'n patetiese onvermoë van die aan sy tydgees verknogte mens om òf sy nalatenskap te handhaaf of om dit tot groter hoogtes uit te bou. Die siening van groot geeste ten spyt, volg die eb onkeerbaar op die vloed. Dit sou uiters gewaagd wees om te voorspel watter ,shallows and miseries" die toekoms gaan ontbloot. Onrusbarende tekens van 'n terugslag van wat Milliken beskou as die belangrikste enkele faktor vir die behoud van menslike geluk, nl. ,a belief in the reality of moral and spiritual values", $\left({ }^{5}\right)$ doen hulle orals voor. Voorbeelde hiervan is mensverering in plaas van Godsverering (ook in Suid-Afrika), die miskenning van die Godgeskape mens, sy bejeëning as blote rat in 'n groot masjien en sy misvorming deur laakbare staatsbeplande propagandamiddels, soos die geval veral in Sowjetbeheerde lande.

Onderwysersopleiding maak ' $n$ inherente deel van die hele onderwyswese uit, en is as sodanig ook onderhewig aan veranderende politieke, maatskaplike en godsdienstige beskouings. $\mathrm{Om}$ die wese van die moderne opleidingsinrigting ten volle te begryp asook nuwe rigtings wat hulle tans ten opsigte van onderwysersopvoeding openbaar, sau dit nodig wees om die geskiedenis van die onderwysersopleiding in besonderhede te beskryf, soos vir sekere lande gedoen is deur o.a. in die doktorale tesis van R. G. Macmillan $\left({ }^{6}\right)$ en die van H. P. van Coller. ( $\left.{ }^{5}\right)$ Weens gebrek aan tyd word daar by hierdie geleentheid verwys alleen na sekere mylpale om o.a. die stelsel van opleiding en die onderwyser van vergange dae met die huidige stelsel en sy produk te kontrasteer; hoofsaaklik in Brittanje en Suid-Afrika.

In Engeland het R. Mulcaster (1530?-1611) die ondërwys met die mees verhewe beroepe vergelyk en 'n stelsel van onderwygersopleiding

(3) A Philosophy of Education. Q. A. Kuehner. Prentice-Hall, :Inc: :1936.

(4) Q. A. Kuehner, op. cit.

(5). Q. A. Kuehner, op. cit.

(B) A Compartive and Critical Study of Developments in Teacher Training in a Selected Group of Western European Countries. R. G. Macmilaln. Dr. Thesis. 1954 .

(7) Onderwysersopleiding in Brittanje en Transvaal, met Bësondere Verwysing na die Britse Beinvloeding hier te lande gedurende die Eerste' Helfte van die 20e eeu. H. P. van Coller. Dr. Thesis. 1957. 
hopleit wat die Engelse Institute van Opvoedıng 350 jaar vooruitgeloop het. Die agttiende-eeuse nasionale Pruisiese stelsel van onderwys wat so 'n groot invloed op die Wes-Europese opvoeding het en Francke se Seminarium Praeceptorum vir die voorbereiding van onderwysers (1696) ten spyt, was die negentiende eeu 'n tydperk van laagwatermerk wat betref onderwysersopleiding. Sir Walter Scott se Dominie Sampson is 'n geleerde dwaas, 'n karakatuur van 'n onderwyser. In 1947 het Macaulay onderwysers bestempel as ,the refuse of other callings". In 1837 het die Sekretaris van die Kaapkolonie gewag gemakk van die vooroordeel teen die onderwysberoep, en rondreisende onderwysers bestempel as "generally drunken and disreputable characters. $\left(^{s}\right)$ Stel hierteenoor die status van die hedendaagse onderwysers en die rol wat hulle in die wyere gemeenskap speel.

In Engeland is die monitorstelsel van Bell and Lancaster vervang deur die Leerlingonderwyserstelsel van Kay Shuttleworth, wat voortgeduur het tot in die twintigste eeu. Die eerste opleidingsinrigting in Skotland, die Glasgow Normal Seminary, is in 1837 gestig, die eerste in Engeland te Battersea in 1840 en, in die Verenigde State van Amerika, die eerste Staatsopleidingskollegete Lexington, in 1839. Teen die einde van die negentiende eeu was daar 'n groot aantal opleidingskolleges in Engeland, sommige, oos die Day Training Colleges, in noue verband met universiteite, ander onder sentrale, lokale of private beheer. Van koördinasie van onderwysersopleiding was daar geen sprake nie. Dieselfde het gegeld vir die Ecole Normale in Frankryk en die Opleidingskole in Holland. Dit is eers as gevolg van die aanbevelings van die McNairkommissie en die daaruit voortvloeiende wetgewing van 1944 dat 'n gekoördineerde stelsel van onderwysersopleiding in Engeland bewerkstellig is. In Skotland het die beheer oor opleiding tot 1905 by die kerk berus, daarna by die provinsiale komitees en vanaf 1920 by die National Committee for the Training of Teachers. In Suid-Afrika was die eerste onderwysers die „Sieckentroosters". Die leerlingonderwyserstelsel is deur Langham Dale in 1859 ingestel, ( $\left.{ }^{\circ}\right)$ maar alreeds vroeër is onderwysers en onderwyseresse deur Somerset en Innes uit Engeland ingevoer. Die eerste Normaalkollege is in 1878 in Kaapstad deur die Hollandse Kerk gestig. In Transvaal was die op-

(8) A History of Education in South Africa (1652-.1932). M. E. McKerron. J. L. van Schaik, Ltd. 1934.

(9) Education in South Africa (1652-1922). E. G. Malherbe. Juta and Co. 1925. 
leiding van onderwysers op die lees van die leerlingonderwyserstelsel van Engeland en Holland geskoei. Eers in 1896 is 'n Normaaldepartement by die Staatsmodelskool in Pretoria gevoeg. Goevernementskennisgewing no. 396 van 1902 is van groot belang in die geskiedenis van onderwysersopleiding in Transvaal. Dit het as gevolg gehad die stigting van die Normaalkollege in 1902 op Pretoria. Die Heidelbergse en Johannesburgse kolleges is in 1909 gestig en die Potchefstroomse in 1919. Opleidingskursusse is aan die T.U.K. in 1912 en P.U.K. in 1921 ingestel. $\left({ }^{10}\right)$ Ander belangrike mylpale in die geskiedenis van die onderwysersopleiding in Transvaal is die Smuts-wet van 1907, wat betref beheer oor die opleiding en die vasstelling van onderwyskwalifikasies, die bepaling dat die opleiding vir die 03- en O2-sertifikate eers na matrikulasie kan plaasvind (1918), die samewerking tussen universiteite en opleidingskolleges, die instelling van die Transvaalse Onderwysersdiploma in 1935 en van die Laer- en Hoër-Onderwysersdiploma in 1937, die daarstelling van Streekkomitees, die toekenning van 'n hoë mate van outonomie aan kolleges wat betref die aard van die opleiding, leergange en sertifisering in 1940, die opleiding van laerskool- sowel as hoërskoolonderwysers aan universiteite, na-uurse opleiding om die tekort aan onderwysers die hoof te bied en die daarstelling van 'n departementele Adviserende Raad insake onderwysersopleiding in 1957. Vandag het ons stelsels van opleiding aan universiteite en kolleges in Transvaal wat gunstig met die van die meeste oorsese lande vergelyk.

Sekere strekkinge het veral teen die begin van die 20ste eeu na vore getree. In Protestantse lande het die staat in toenemende mate beheer oor die onderwysersopleiding op hom geneem. In oorwegend Rooms-Katolieke lande doen die Kerk beswaarlik afstand van gevestigde regte, en bly ' $n$ toestand van dichotomie in groot mate voortbestaan. In Suid-Afrika, waar die opleiding van hoër- en laerskoolonderwysers of onder universiteite òf provinsiale departemente ressorteer, is daar 'n groot gebrek aan uniformiteit. Soos P. S. du Toit tereg opmerk is daar onrusbarende uiteenlopendheid met betrekking tot byna alle aspekte van die onderwysersopleiding. $\left({ }^{11}\right) \mathrm{Hy}$ beveel aan dat alle onderwysersopleiding aan universiteite verbind moet word. Die

(10) Onderwys in Transvaal (1838--1937), J. C. Coetzee. Van Schaik Bepk. 1941.

(11) Aspects of Teacher Education in the U.S.A., Canada and South Africa. P. S. du Toit. Verslag. 1956. 
De Villierskommissie beveel aan dat die „huidige opleidingskolleges . . . in opleidingsinrigtings omskep word wat samestellende kolleges van die Universiteit sal wees". $\left({ }^{12}\right)$ In 'n dissertasie van die Onderwysburo $\left({ }^{13}\right)$ word ook melding gemaak van die gebrek aan uniformiteit van onderwysersopleiding, en word aanbeveel dat professionele opleiding die verantwoordelikheid van provinsiale departemente behoort te wees, 'n standpunt wat onderskryf word deur die Nicolkommissie, nl. dat onderwyskolleges ,regstreeks onder die beheer van die Direkteur van Onderwys moet staan ....." (")

Dat daar 'n groot behoefte aan beter koördinering van onderwysersopleiding in Suid-Afrika bestaan, ly geen twyfel nie. 'n Nasionale Raad vir Onderwysersopleiding sou o.a. na aanleiding van bestaande behoeftes die aard, omvang en duur van veskillende kursusse bepaal, en die ekwivalering van kwalifikasies behartig, maar die direkte beheer moet uitgeoefen word deur 'n liggaam wat weens sy verantwoordelikhede teenoor en sy kennis van die skole wat hy dien die beste daartoe in staat is. "Too much centralisation and organization crush the spirit of the educational genius". F. Clarke. $\left({ }^{15}\right)$ of dit die huidige strekking in oorsese lande is om universiteite vir alle professionele opleiding verantwoordelik te hou is 'n vraag waarop geen afdoende antwoord gegee kan word nie. Teenoor die Delegacies in Engeland word die National Committee for the Training of Teachers in Skotland gestel. Die Teachers' Colleges van die Verenigde State word deur die voorstanders van universiteitsbeheer sowel as die van selfstandige kolleges of kolleges onder beheer van provinsiale departemente uitgebuit. Selfs in Engeland, waar die Delagacies van die universiteite in groot mate kontrole oor onderwyskolleges as gevolg van die McNairverslag verkry het, bv. ten opsigte van leergange en eksaminering, geniet hierdie geassosieerde kolleges wisselende grade van outonomie. Die Dudleykollege onderskei hom van ander kolleges weens die klem wat hy op Sosiale Studies lê en die toepassing van 'n besondere stelsel van

(12) Verslag van die Kommissie insake Tegniese en Beroepsonderwys. Uitgegee op Gesag. Die Staatsdrukker, 1948.

(13) A Dissertation on Teacher Education. Education Bureau, Transvaal Education Department, 1954.

(14) Verslag van die Provinsiale Onderwyskommissie, Provinsie Transvaal. Staatdrukker, 1939.

(15) Aanhaling uit Teacher Training. Some Recommendations. P. McMagh. Report Submitted. 1952. 
vakkeuse. Die bevinding van Macmillan is dat, by die ontevredenheid met onderwysersopleiding in baie lande, daar ' $n$ uitgesproke begeerte is vir meer kobrdinering van opleidingsprogramme, beter integrasie van die hele opleidingstelsel in 'n demokraties geöriënteerde sosiale struktuur, en vir wat hy noem, ,a wholeness of outlook on the part of the teacher". $\left({ }^{11}\right)$ Om hierdie oogmerk te verwesendik, moet opleiding langer duur, beter integrasie tussen stof en metode bewerkstellig word, en alle kragte ingespan word om die hele persoonlikheid van die kwekeling te ontwikkel. Hy kom tot die slotsom dat die Onderwyskollege beter as die Universiteit aan bogenoemde eise van professionele opleiding kan voldoen.

By hierdie eise kon die aangehaalde skrywer die belangrikste van alle eise meer beklemtoon het, $n l$. dat ' $n$ onderwysersopleidingsinrigting, net soos die indiwidu, vooraf moet bepaal wat hy as die hoogste waardes in die lewe beskou. As hierdie waardes nie net van momentele aard moet wees nie, moet hulle afgelei word van 'n bepaalde lewens- en wêreldbeskouing, d.w.s. van die standpunt wat teenoor die sigbare en onsigbare ingeneem word. Veral in die huidige wêreld van "warring elements" lê die antwoord op wat vir hom en sy instellings as rigsnoer moet dien opgesluit in die woorde: „Maar soek eers die koninkryk van God en sy geregtigheid, en al hierdie dinge sal vir julle bygevoeg word". Die strewe en werk van 'n opleidingsinrigting wat onderwysers en onderwyseresse vir ons Christelike skole voorberei, moet deurtrek wees van die Christelike lewensfilosofie. Dit veronderstel ,hulpverlening aan en leiding van die nog onrype, onmondige, onselfstandige jongmens, sodat hy, wanneer hy tot die stadium van rypheid en selfstandigheid kom, iets sal bereik het wat die opvoeder as nastrewenswaardig beskou, en wat vir die opvoeder die hoogste waardes in die lewe beliggaam".(")

Terwyl dit geredelik toegegee sal word dat doelstelling oneindig makliker is as doelverwesenliking, is dit tog opvallend dat menige opleidingsinrigting nie 'n duidelike begrip van oogmerke daarop nahou nie. 'n Ondersoek in die V.S. van Amerika aan 28 kolleges wat hulle toelê op hoërskoolonderwyseropleiding het aan die dig gebring dat

(16) R. G. Macmillan, op. cit. b.4.

(17) Onderwysersopleiding. Die Rektor, Personeel en Verteenwoordigende Studenteraad van die P.O.K. Pro Rege-Pers Bepk., 1954. 
daar byna net soveel doelstellings as kolleges is. $\left({ }^{18}\right)$ Wat ook uit hierdie ondersoek geblyk het, is die skeiding tussen doelstelling en leerplan, tussen metode en die student se „Kampuslewe". Hierdie ondersoek het vir die betrokke kolleges die vrug van herevaluering van verbandhoudende en prakties uitvoerbare waardebepalings afgewerp. Die uitlewing van die vooropgestelde Christelike doel van die opleiding vereis daelikse inspanning, voortdurende herevaluering van stof, metode en persoonlikheid en van daardie liefde wat soveel verdra en vermag.

Opvallend is die beklemtoning in alle lande van die noodsaaklikheid van persoonlikheidsvorming gedurende die jare van emosionele aanpassing. Opvallend ook is dat daar so baie rondgetas word om te weet juis hoe dit bewerkstellig moet word. Op verskeie wyse het die plaaslike Onderwyskollege oor die laaste 20 jaar hom die bepaalde taak van persoonlikheidsvorming op alle terreine opgelê waarop studente beweeg, asook die moeilike taak van persoonlikheidsevaluering. In toenemende mate word orals aandag aan hierdie aspek van die opleiding geskenk. V. E. Herrick meen dat voorspelling van wat hy noem „teacher success" in die toekoms al meer en meer van voldoende analise van onderwyserspersoonlikheid sal afhang. $\left({ }^{10}\right)$

Doelgerigte persoonlikheidsvorming hang in groot mate af van indoktrinasie, van 'n gesonde verhouding van wedersydse vertroue tussen dosent en student, en van 'n fyn georganiseerde stelsel van opleiding wat dosente in verskillede kapasiteite in gedurige aanraking met studente bring. Indoktrinasie is geregverdig slegs as dit rekening hou met die nasionale strewe, gebruike en tradisies en die eise van die opvoeding en onderwys aan ons skole, en as dit strook met ons Christelike lewensbeskouing. Dit word vergemaklik deurdat studente aan kolleges deesdae uit homogene groepe bestaan. Voorbeelde van pogings om die kwekeling se persoonlikheid te meet, is Burroughs se Batterytoets van die Universiteit van Birmingham $\left({ }^{20}\right)$ en, wat betref die afgestudeerde student, die questionnaire van die Amerikaanse The College of Scholastica.( $\left.{ }^{\mathrm{n}}\right)$

(18) Better Collegeg-Better Teachers. R. M. Cooper and Collaborators. Macmillan Co. Printings. 1944.

(19) Our Future in Teacher Education. V. E. Herrick. Teachers College Record. Vol. 57.

(20) R. G. Macmillan, op. cit. b.4

(21) R. M. Cooper, op. cit. b.9. 
Dit is wel moontlik om met 'n mate van sekerheid 'n aantal fasette van persoonlikheid te evalueer volgens ' $n$ vyf- of tienpuntskaal, veral as die oordeelvellinge van 'n groot aantal persone in 'n groot verskeidenheid situasie in berekening gebring word. Die totale beeld is egter nie noodwendig die som van die konstituerende dele van die persoonlikheid nie. Selfs net 'n ,dram of eale" of "some vicious mole of nature", een klein onvolkomenheid kan die totaal van die mooiste eienskappe bederf. „Hoog het hy (Efraim) gestaan in Israel. Maar hy het hom skuldig gemaak aan Baäl en gesterwe". Die moeilikheid om persoonlikheid te meet ten spyt, is pogings daartoe prysenswaardig in soverre hulle die student, deur sy aandag op gewenste eienskappe te vestig, 'n opleidingsmotief, -strewe en -bestemming verskaf. Geleid en geïnspireer deur die ideaal van Christelike volmaaktheid, moet voortdurend gepoog word om die vir indruk vatbare jongmens tot 'n geïntegreerde persoonlikheid om te skep. Soos Coetzee dit stel: „Die integrasie van die persoonlikheid is die vrug van goeie opvoeding en leiding en van gesonde ontwikkeling". $\left({ }^{12}\right)$

In talle verslae, geskrifte en toesprake word opvoeding en onderwys as ' $n$ staat se belangrikste taak beskryf, en word die onderwysers aangewys as die spil waarom alles draai. Vir gewenste persoonlikheidsontwikkeling is ' $n$ betreklike lang opleidingsperiode nodig. In sommige lande begin opleiding op die ouderdom van 13 of 14 jaar en duur dit 2, 3 of 4 jaar. $\left({ }^{23}\right)$ Die huidige strekking is duidelik: opleiding moet begin eers nadat die student 'n sekere akademiese peil behaal het, gewoonlik matrikulasie (die baccalaureat in Frankryk), en moet verleng word vanaf die oral voorkomende tweejaaropleiding na drie of vier jaar, selfs vir die laerskoolonderwyser, soos tans die geval in Skotland en baie van die meer as 1200 opleidingsinrigtings van die V.S. van Amerika die geval is. Die groot tekort aan onderwysers het 'n noodgedwonge verkorting van die opleidingsduur veroorsaak, bv. in Engeland het die Noodopleidingstelsel van 1944, as gevolg waarvan 35,000 onderwysers en onderwyseresse opgelei is, oor een jaar gestrek. $\left({ }^{24}\right)$ Ook in Transvaal is daar, nadat die driejarige kursus in 1935 vir onderwyseresse aan laerskole ingestel is, teruggekeer na 'n

(22) Inleiding tot die Algemene Empiriese Opvoedkunde. J. C. Coetzee. Pro Ecclesia-Drukkery. 1948.

(23) Primary Teacher Training. Unesco. 1963.

(24) Growth in English Education (1946-1952). H. C. Dent. Routledge and Kegan Paul. 1964. 
tweejarige kursus vir die Laer Onderwysersdiploma om die tekort aan onderwysers die hoof te bied - 'n maatreël wat hopelik van tydelike aard sal wees.

Net soos opvoeding en onderwys aan die skool in nouer verband met toestande in die groot gemeenskap en die eise wat die gemeenskap aan die individu stel, gebring moet word (in ooreenstemming met die beskouings van opvoedkundiges soos James, Dewey, Kersakensteiner en Decroly), so ook moet opleiding hom inskakel by die nuwe eise wat aan beide skole en die wyere gemeenskap gestel word. Waar die klem in die verlede op die akademiese was, is dit vandag op die professionele en sosiale aspek van die opleiding. Tog word in etlike lande 'n suiwer akademiese opleiding as genoegsame kwalifikasies vir onderwys aan hoërskole geag. ${ }^{23}$ ) Op die vasteland van Europa bestaan die onewewigtigheid van menige opleidingsprogram juis in die oorbeklemtoning van die akademiese ten koste van die professionele. Selfs waar die professionele aspek van die opleiding in groot mate tot sy reg kom, soos die geval in Transvaalse Onderwyskolleges, word te veel tyd aan die inhoudelike van die skoolvakke gewy.

Tyd ontbreek om die veranderinge van die leerplanne vanaf die stigting van die eerste opleidingsinrigtings tot vandag in besonderhede te beskryf, en hier word verwys slegs na die leerplan van die eerste opleidingsinrigting in Engeland, te Battersea. Aan hierdie inrigting is 66 uur per week aan verpligte vakke gewy. $\left({ }^{20}\right)$ 'n Analise van hierdie Hercules-arbeid toon dat met uitsondering van 15 uur per week wat aan proefonderwys gewy is en 1 uur aan Pestalozzi, die aandag van die student die orige tyd deur skoolvakke in beslag geneem is. Die negentiende eeu het die wat in die opvoeding beklemtoon en die hoe (en gevolglik die opvoedeling) verontagsaam. Veral na die aanvang van die $20 \mathrm{e}$ eeu, en as gevolg van die belangstelling in en studie van die psigologie en sosiologie, het 'n ,nuwe opvatting en behandeling van die wordende mens geleidelik tot stand gekom" $\left({ }^{27}\right)$ en is die klem verskuif na die by die opvoedeling aangepaste leerplan en leergang, en na opvoedeling-gerigte onderwys - in beide skool en opleidingsinrigting.

Hoewel ons huidige Transvaalse Onderwyskolleges, wat betref die beoogde persoonlikheidsvorming, opleiding tot algemene professionele

(25) Secondary Teacher Training. Unesco. 1954,

(26) R. G. Macmillan, op. cit. b.4.

(27) J. de W. Keyter, op. cit. b.2. 
bruikbaarheid en praktiese beroepsvoorbereiding, gunstig vergelyk met die van die meeste soortgelyke oorsese inrigtings, wil dit my tog voorkom dat die tyd vir drastiese herevaluering van sekere aspekte van die opleidingsprogram noodsaaklik geword het. Die aanhaling uit die MeNairverslag ( $\left.{ }^{28}\right)$ nl. „Many students in Training Colleges do not mature by living: they survive by hurrying", is in 'n mate van toepassing ook op die studente van ons kolleges, veral die studente wat die tweejarige kursus volg. Nie alleen is hierdie kursus te kort nie, maar alle kursusse is oorlaai. Die aantal verpligte vakke kom op by en om 20 te staan, en die lesingsdrag op 35 tot 41 periodes per student per week. Van elke student word verwag dat hy moet deelneem aan aktiwiteite op verskillende opleidingsterreine en krediete vir opsionele vakke verwerf. Van selfstandige werk en verdiepte studie van die Opvoedkunde, waartoe veral die gegradueerde student geleenthede gebied moet word, kom nie genoeg tereg nie. Die huidige opleidingsprogram skuif te veel in breedte ten koste van diepte uit. Dit kan toegeskryf word aan die pragmatisme van hierdie eeu en die verwagting was skole koester dat die pasafgestuurde onderwyser alreeds die „tricks of the trade" moet kan bemeester. Die bewering dat die opleiding aan universiteit of kollege te min verband hou met die onderwyspraktyk en te teoreties is, word dikwels gemaak. Om toe te sien dat die student vir sy onmiddellike taak voorberei word, terselfdertyd langs menigvuldige weë die gewenste persoonlikheid te vorm en die regte gesindheid aan te kweek, m.a.w. om kennis, tegniek en deugdelikheid in ooreenstemming met sekere fundamentele beskouings met mekaar te versoen - dit is die taak wat die opleidingskollege hom oplê.

Die neiging in menige moderne opleidingsinrigting is om die inhoudelike van die skoolvakke drasties te besnoei. Dit is die taak van die inrigting om die student alleen die fundamentele beginsels van die metodologie van aanverwante vakke te leer op so 'n wyse dat hy hulle self kan toepas; verder, om hom op hoogte te bring met bronne wat hy vir die inhoudelike en die besonderhede van die metodologiese kan raadpleeg.

Besnoeiing kan ook bewerkstellig word deur die repetitiewe wat gepaard gaan met die metodiekonderrig vir alle laerskoolvakke, en selfs verbindinge van sekere hoërskoolvakke, uit te skakel. Dit kan bereik word deur samesprekings tussen die betrokke dosente, deur hersiening

(28) P. McMagh, op. cit. b.7. 
en versigtige beplanning van leergange, en deur die groepering van aanverwante vakke soos bv. Aardrykskunde, Geskiedenis, Burgerkunde, Bantoekunde en Padveiligheid vir metodiekdoeleindes; of om hierdie vakke om te skep tot 'n nuwe geheel soos tewens aanbeveel is in die Verslag oor Sosiale Studies. $\left({ }^{\mathrm{m}}\right)$

In hierdie verslag word die oogmerke van Sosiale Studies duidelik gestel. Samevattend kan gesê word dat die doel van Sosiale Studies is die koordinering en integrasie van vakke wat in die verlede te los van mekaar gestaan het op so 'n wyse dat die leerling die verband tussen skool, die indiwidu en die gemeenskap in die regte perspektief te sien kry.

Terwyl daar gewaarsku moet word teen die aanvaarding van enige nuwe gedagte wat van elders na ons oorgewaai kom, en wat as gevolg die verwatering van kennis van basiese bestaande vakke kan hê, moet pogings tot beter integrasie van kennisgebiede en tot gepaste sosialisering van die skoolwerk verwelkom word.

'n Aantal opleidingskolleges in Engeland bied alreeds Social Studies of Environmental Study as vak aan, bv. in Birmingham Training College word Environmental Study uit Aardrykskunde, Geskiedenis, Burgerkunde en Biologie saamgestel. $\left({ }^{30}\right)$ In A Handbook of Social Studies van Dray en Jordan verskyn 'n interessante program vir die onderwys van Sosiale Studies. Dit wil voorkom dat besondere waarde geheg word aan selfstandige ondersoek deur middel van uitstappies na vir die studie nuttige besienswaardighede, indiwiduele navorsing, raadpleging en navraag, die gebruik van films, doelgerigte lees en baie groepsbesprekings. $\left({ }^{31}\right)$

Dat die basiese kursus van opleidingsinrigtings hier te lande asook oorsee oorlaai is, blyk uit die ondersoek wat die plaaslike kollege in 1956 ingestel het en in verslagvorm an die Departement van Onderwys voorgelê het. ${ }^{33}$ ) In hierdie ondersoek word o.a. gewag gemaak van die vervlakking wat die byvoeging van vakke by 'n alreeds oorlaaide program as gevolg gehad het. Daar word aanbeveel dat, in ooreenstemming met die jongste ontwikkelinge in sommige oorsese opleidingsinrigtings, die inhoudelike van skoolvakke, met die uitsondering

(29) Verslag oor Sosiale Studies. T.O.D., 1956.

(30) R. G. Macmillan, op. cit. b.4.

(31) R. G. Macmillan, op. cit. b.4.

(32) 'n Ondersoek na die Relatiewe Aksentuasie van Voorgeskrewe Vakke in die Leerplanne van Onderwyskolleges, P.O.K. 1956. 
van die twee landstale, gesnoei en die repetitiewe in de metodiek van laerskoolvakke uitgeskakel word; om die student se periodelas verder te verminder deur 'n ruimer keuse van vaardigheids- en ander vakke toe te laat (ook met die oog op gedifferensieerde onderwys), en om beter integrasie van aanverwante vakke deur groepering te bewerkstellig. Verligting van die periodelas is alreeds ter plase langs een of meer van die aanbevole weë aagebring, en verdiepte studie van die metodiek van hoërskoolvakke bewerkstellig.

Ook ten opsigte van onderwyseenhede en metode van onderrig kan heelwat verbeteringe aangebring word. Dit gebeur alte dikwels dat, as gevolg van die snel toenemende aantal studente aan onderwyskolleges en van verknogtheid aan geykte metodes van onderrig, lesings aan groot groepe studente gegee word. Oor die grootte van onderwyskolleges is daar meningsverskil, maar al die kolleges is die mening toegedaan dat ware opleidingswerk ten beste verrig word met klein groepies. Voorlesings aan groot groepe werk passiwiteit in die hand. Ontmoetings met klein groepies bied geleentheid vir die aanbieding van referate deur indiwiduele studente, vir beter leiding en persoonlikheidsvorming en vir groepbespreking. Laasgenoemde is 'n metode wat veral in die kolleges van die V.S. van Amerika, soms selfs in oordrewe vorm toegepas word. $\left({ }^{s y}\right)$

Tot kort voordie einde van die negentiende eeu was die opvoeding van die kind in groot mate beinvloed deur wysgerige beskouings van 'n aantal denkers. Die 20ste eeu staan gekenmerk (wat opvoeding betref) deur die intensiewe studie van die kind se sielelewe ooreenkomstig 'n groot verskeidenheid sielkundige opvattings of rigtings, soos bv. die Behaviorisme, die Gestaltsielkunde, die Hormiese sielkunde, met die daarmee gepaardgaande metodes van ondersoek. $\left({ }^{(4)}\right)$ Vir die opvoeder bestaan die waarde van al hierdie kinderstudie daarin dat hy 'n duideliker insig in die siel van die kind kry en sy opvoeding en onderwys daarvolgens inrig. Persoonlikheidsvorming, in ooreenstemming met sekere fundamentele beginsels, bly die hoofdoel van opvoeding. Dit kan bes geskied waar dit die nodigste is, nl. aan 'n opleidingsinrigting, op voorwaarde dat die groepe klein is, aangesien persoonlikheidsbeinvloeding grootliks afhang (soos in die huis) van 'n persoonlike, intieme verband tussen opvoeder en opvoedeling. Sodanige stelsel van klein

(38) P. S. du Tolt op. cit. b.6

(34) J. C. Coetzee op. cit. b.11. 
onderwyseenhede bring noodwendig ruimer personeelvoorsiening mee en, wat belangriker is, die benoeming van die aristoi van die onderwysprofessie aan onderwyskolleges wat nie ten volle verwesenlik sal word nie alvorens die status en besoldiging van die dosent in ooreenstemming met die belangrikheid en verantwoordelikheid van sy werk gebring word.

'n Ander strekking in beide die sekondêre skool en die onderwyskollege is die van differensiasie. Tot dusver is differensiasie aan Transvaalse Onderwyskolleges toegepas hoofsaaklik ten opsigte van spesialiseringskursusse en die metodiek van hoërskoolvakke. Die basiese kursus, bestaande uit 'n groot aantal verpligte vakke, word vir alle studente, vir gegradueerdes sowel as slegs gematrikuleerdes, voorgeskrÿf. Die tekort aan bevoegde hoërskoolonderwysers is vandag onrusbarend, soos blyk bv. uit die ondersoek na hierdie vraagstuk in die Kaapprovinsie deur Slabber. Die H.O.D.- en U.O.D.-student word vandag byna sonder uitsondering aan 'n hoërskool benoem. Die vraag mag wel gestel word waarom dit vir die H.O.D.-student nodig is om die metodiek van 8 laerskoolvakke te bestudeer, waarom hy nie kennis moet mak slegs met die fundamentele metodologiese beginsels van aariverwante vakke nie, en hom bepaal by die metodiek van sy hoofvakke vanaf die grade tot en met Std. 10.

Volgens die ondersoek waarna so-ewe verwys is, is daar 'n nypende tekort aan onderwysers wat ten volle bevoeg is om veral die vakke Matesis en Engels te onderrig: $47 \%$ van die onderwysers en onderwyseresse in die Kaapprovinsie aan wie Matesisonderrig toevertrou is, het geen universitêre opleiding in Matesis gehad nie, en 'n soortgelyke toestand bestaan wat betref Engels. $\left({ }^{38}\right)$ Vir geruime tyd en in toenemende mate word die nie-gegradueerde student na driejarige opleiding met ontoereikende gespesialiseerde kennis van haar vak benoem om selfs in die hoogste klasse van die hoërskool haar vak te onderrig (in Engeland selfs na 'n opleidingsduur van twee jaar, veral in die Secondary Modern School). Enersyds is onderwys en opvoeding in die laerskool 'n gevoelige slag toegedien deur die instelling van die tweejarige kursus, andersyds die hoërskool deur die benoeming van 'n antal onbevoegde onderwysers en anderwyseresse. As gevolg van die Onderwysdepartement se progressiewe beleid en die groot toename van kwekelinge aan onderwyskolleges behoort die agterstand ten opsigte

(35) P. S. du Toit, op. cit. b.6. 
van hoërskole in Transvaal binne afsienbare tyd ingehaal te word.

Vir die onderwys aan laerskole word in die vooruitsig gestel slegs 'n opleidingskursus na matrikulasie aan onderwyskolleges wat minstens drie jaar sal duur. Gedurende die eerste twee jaar word 'n basiese kursus aangebied, beter geintegreer as wat tans die geval is, deur alle vakke nouer te verbind met kernvakke soos Teoretiese en Praktiese Opvoedkunde, Kindersielkunde, Godsdiens- en Gesondheidsopvoeding. Aan die begin van die derde jaar word die student voor 'n wye keuse gestel - 'n uitbreiding van die Engelse stelsel yan ,,special subjects" en in ooreenstemming met die stelsel van ,age range specialisation". Bo en behalwe die tansbestaande spesialiseringsrigtinge of vakke, en by verpligte, meer gevorderde kursusse in minstens die twee landstale, word die student voor ' $n$ wye keuse van vakke of kombinasies van vakke gestel, soos bv. Sosiale Studies, 'n nie-spesialiserende kursus in die Kunste, Sakekennis, Volkekunde, Matesis, Geskiedenis, Spraakopleiding en ander. Hierdie derde jaar bied uitstekende geleentheid vir differensiasie van kursusse, vir opleiding wat studentgerig is, vir selfstandige studie, vir praktese voorbereiding : vir die skooltaak, aangesien proefonderwys as 'n belangrike deel van die opleiding bly voortbestaan en, les bes, vir die belangrike taak van persoonlikheidsvorming. Hierdie stelsel van opleiding moet egter nie vir die onderwys aan hoërskole uitgebuit word nie. Dit kan nie genoeg beklemtoon word nie dat enige veranderinge van duur en inhoud van kursusse met sig moet meebring beter voorbereiding van die kwekeling vir sy belangrike taak as opvoeder --- en hoër status as onderwyser.

Melding is gemaak van die klemverskuiwing vanaf die inhoudelike na die vakmetodologiese, van die suiwer akademiese na die professionele aspek van die opleiding. Die professionalisering van die akademiese vakke geniet vandag baie aandag in oorsese lande, In die vrye maar gewoonlik geakrediteerde graaduitreikende Teachers Colleges van die Verenigde State van Amerika, word die versoening van die akademiese en professionele aspekte van die opleiding vergemaklik. Interessant is die kursus wat deur die Universiteit North Staffordshire in Brittanje aangebied word, omdat dit die integrasie van die akademiese en professionele aspekte van die opleiding beoog. $\left({ }^{*}\right)$ In Engeland en Skotland word (selfs in sommige skole) baie aandag

(36) R. G. Macmillan, op. cit. b.4 
aan professionele oriëntering geskenk. Die ondervinding leer trouens in Transvaal dat die student wat sy graad aan 'n universiteit behaal het in menige opsig van meet af aan weer in sy vierde jaar vir sy werk ingestem moet word. Gevestigde instellings, soos universiteite, openbaar baie maal 'n sterk neiging tot ultra-konserwatisme. Hulle is gesteld op die handhawing van die akademiese peil en gevestigde gebruike, soms ongeag die eise wat die lewe in die wyere gemeenskap aan hulle produkte stel. Dit is opvallend met hoeveel huiwering sommige universiteite die belangrikste van alle volkstake aanvaar, nl. die opleiding van onderwysers en die studie van die wetenskap Opvoedkunde. Deur die onderwysers wat hy oplei, bereik die universiteit die volk. Genoemde aantyging kan egter nie die P.U. vir C.H.O. ten laste gelê word nie.

Die vraag is of die universiteit wat onderwysers oplei nie tans ook voor 'n differensiasie-probleem te staan gekom het nie. 'n Duidelik bespeurbare strekking in moderne onderwysersopvoeding is die benadering van die opleiding in sy totaliteit, van pogings om alle aspekte daarvan in een groot geheel te integreer, om die dikwels uiteenlopende elemente tot 'n diapason om te skep. Tans is daar te min verband tussen die akademiese en die professionele deel van die opleiding. Die gewenste integrasie kan ten dele langs verskillende weë onder huidige omstandighede bereik word, maar nie ten volle nie, alvorens 'n professioneel-opgeleide personeel die nodige professionele bias aan akademiese vakke gee binne 'n meer selfstandige Departement van Opvoeding.

Dit was moontlik om binne die bestek van hierdie rede die aandag op slegs enkele aspekte en strekkinge ten opsigte van onderwysersopleiding te vestig, gesien teen die historiese agtergrond daarvan:

Eerstens, die rewolusionêre ontwikkelinge op die terrein van die onderwysersopleiding gedurende die afgelope 50 jaar en meer, en die aanvaarding uit allerlei oorde van die standpunt dat onderwysersopleidingsinrigtinge en -departemente die strategiese sentra van die hele opvoedingstelsel van 'n land is.

Tweedens, die beplanning van 'n steeds toenemend-funksionele opleidingsproses, die benadering daarvan as 'n geheel en die integrering van die verskillende aspekte daarvan.

Derdens, die bestryding van die vervlakking van die opleiding as gevolg van 'n oorlaaide program deur 'n stelsel van wyer vakkeuse, die besnoeiing van die inhoudelike van skoolvakke en die beperking hoof- 
saaklik tot die professionele, die voorkoming van die repetitiewe en die toepassing van beter onderwysmetodes.

Vierdens, die noodsaaklikheid van 'n groter mate van differensiasie tussen verskillende kursusse en binne dieselfde kursus.

Vyfdens, realistiese bevordering langs beplande weë van vir die onderwyser gewenste persoonlikheidseienskappe in ooreenstemming met ' $n$ duidelik-gestelde, stabiliserende en integrerende credo.

Die vloed van die onderwysersopleiding in die twintigste eeu word gekenmerk deur voortreflike vooruitgang ten opsigte van die voorbereiding van die kwekeling vir sy onmiddellike skooltaak; die eb in menige land deur die miskenning van die kardinale eise van die lewe. Daar is egter alreeds orals duidelike tekens van die gewenste sedelike en geestelike ontwaking en herbewapening.

Dit is vir die skrywer hiervan 'n eer om hierdie rede te mag voordra binne die mure van 'n universiteit wat so ' $n$ duidelike siening oor die einddoel van alle opleiding daarop nahou; wat hom in so 'n mate toelê op die belangrikste van alle take wat 'n inrigting vir hoër onderwys hom kan toeëien, naamlik die opleiding van die leermeesters van die jong mense wat die Afrikaner se godsdiens, taal, tradisies en gebruike te midde van dreigende storms sal moet handhaaf en terselfdertyd samewerking met ander volksgroepe sal moet nastreef; 'n inrigting wat, binne die raamwerk van aanvaarde en onveranderlike waarhede, tog sonder aarseling die aanhaling warmee hierdie rede begin het, anvaar:

"The old order changeth, yielding place to new,

And God fulfils Himself in many ways,

Lest one good custom should corrupt the world".

Hooggeagte Here Lede van die Raad van die P.U. vir C.H.O.,

Ek dank $u$ vir diie eer wat $u$ my aangedoen het om my, in my kapasiteit as Rektor van die Potchefstroomse Onderwyskollege, 'n ere-professoraat aan te bied.

Hooggeleerde Rektor, Here Professore, Dames en ere Lektore van hierdie Universiteit en van die Onderwyskollege, aan $u$ betuig ek my dank dat $u$ my so vriendelik in $u$ midde ontvang het en my gulle samewerking gebied het.

Hooggeleerde Prof. J. C. Coetzee, aan u betuig ek, namens die Onderwyskollege, dank vir $u$ hooggewaardeerde raad terwyl $u$ lid van die Kollege se Streekkomitee was. Die samewerking tussen Universiteit en Onderwyskollege was nog altyd oor al die jare van hulle groei 
van die hartlikste, en die aanbod van 'n ere-professoraat deur de Raad aan my is afdoende bewys daarvan.

Geagte Dames en Here Studente, aan $u$ dra ek 'n gebed op wat meer as 700 jaar gelede geskryf is, die gebed waarin die ideale van die Christen-opvoeder kernagtig saamgevat word, die gebed van die heilige Francis d' Assissi:

“O, Divine Master, grant that I may not so much seek to be consoled as to console; to be understood as to understand; to be loved as to love; for it is in giving that we receive; it is in pardoning that we are pardoned and it is in dying that we are born to eternal life".

Dames en Here, ek dank u.

\section{BIBLIOGRAFIE}

1. Ascham, R. The Scholemaster. Arber's English Reports. Constable and Co., Ltd. 1920

2. Campbell, A. E. Modern Trends in Education. Proceedings of the New Zealand N.E.F. Conference. Whitcomb and Tombs, Ltd. 1938.

3. Coetzee, J. C. Inleiding tot die Algemene Empiriese Opvoedkunde. ProEcclesia-Drukkery. 1954.

4. Coetzee, J. C. Onderwys in Transvaal (1838-1837). J. L. van Schaik Bepk. 1941.

5. Coetzee, J. C. Opvoedkundige Teorie en Praktyk deur die Eeue. Voortrekkerpers. 1943.

6. Cooper, R. M. and Collaborators. Better Colleges- Better Teachers. Macmillan Co. Printings. 1944-1947.

7. Curtis, D. K. and Andrews L.O. Guiding Your Student Teacher. PrenticeHall, Inc., N.Y. 1954

8. Dent, H. C. Growth in English Education (1946-1952). Routledge and Kegan Paul. 1954.

9. Du Toit, P. S. Aspects of Teacher Education in the U.S.A., Canada and South Africa. A Report. 1956.

10. Herrick, V. E. Our Future in Teacher Education. Teachers College Record. Vol. 57.

11. Keyter, J. de W. Opvoeding en Onderwys. 1936.

12. Kuehner, Q. A. A Philosophy of Education. Prentice-Hall, Inc. 1936.

13. Learned, W. S. and Others. The Professional Preparation of Teachers for American Public Schools. The Merrymount Press, Boston.

14. Macmillan, R. G. A Comparative and Critical Study of Developments in Teacher Training in a Selected Group of Western European Countries. Dr. Thesis. 1954. 
15. McMagh, P. Teacher Training. Some Recommendations. Report Submitted. 1952.

16. Malherbe, E. G. Education in South Africa (1652-1922). Juta and Co. 1925.

17. McKerron, M. E. A History of Education in South Africa. J. L. van Schaik, Ltd. 1954.

18. Mitchell, W. F. and Beaulavon, G. The Training of Teachers. Evans Bros., Ltd.

19. P.O.K. 'n Ondersoek na die Relatiewe Aksentuasie van Voorgeskrewe Vakke in die Leerplanne van Onderwyskolleges. 1956.

20. P.O.K. Die Rektor, Personeel en Studenteraad van die Potchefstromse Onderwyskollege. Onderwysersopleiding. Pro Rege-Pers Bepk. 1954.

21. Report. A Final Report by the Commission on Teacher Education. American Council on Education. The Improvement of Teacher Education. Washington, D.C. 1946.

22. T.E.D. Education Bureau. A Dissertation on Teacher Education. 1954.

23. Unesco. The Education and Training of Teachers. 1948.

24. Unesco. Primary Teacher Training. 1953

25. Unesco. Secondary Teacher Training. 1954.

26. Van Coller, H. P. Onderwysersopleiding in Brittanje en Transvaal met Besondere Verwysing na die Britse Beïnloeding Hier te Lande gedurende die Eerste Helfte van die 20ste Eeu. Dr. Thesis. 1957.

27. Verslag oor Sosiale Studies. Tussentydse Verslag van die Departementele Komitee insake Toetsing, Promosie en Kurrikulum in die Laerskool. T.O.D. 1956.

28. Verslag van die Kommissie insake Tegniese en Beroepsonderwys. Uitgegee op Gesag. Die Staatsdrukker. 1948.

29. Verslag van die Provinsiale Onderwyskommissie, Provinsie Transvaal. Die Staatsdrukker. 1939. 